Ann. Biol. anim. Bioch. Biophys., 1977, 17 (5 A), 661-672.

\title{
Action of Busulfan on larval gonads of the Colorado Beetle Leptinotarsa decemlineata Say (Coleoptera, Chrysomelidae)
}

par Noëlle RICHARD-MERCIER

Loboratoire Sexualifé ef Reproduction des Invertébrés Universifé Pierre ef Marie Curie

Bat. A, 4 place Jussieu, 75230 Paris Cedex 05, France.

Summary. Implantation of a busulfan crystal into larvae of first, second and third instars temporary blocks molting. In gonad this antimitotic only acts on one category of germinal cells : secondary spermatogonia. During mitosis chromosomal changes lead to cellular death. However all the gonia are not affected by a single dose of busulfan.

Busulfan or 1-4 dimethylsulfonyloxybutane is an antimitotic of the sulfonylalkane group. This alkylant agent inhibits cell division in tissues proliferating at a high rate. Bollag (1953) was the first author to inject busulfan into pregnant rats ; their male and female progeny were completely sterile. The effect of busulfan on the gonads of embryonic and adult mammals has been frequently studied; it causes chromosomic lesions inducing degeneration of the affected germ cells and gonadic sterilization. However, this product has been little used on invertebrates. When mixed into the feed of the adult Coleoptera Anthonomus grandis (Klassen. Nordland, Borkovec, 1968), busulfan did not completely sterilize the males. These authors considered busulfan as a promising antimitotic. Injecting this product into a Peracarid Amphipod Crustacean, Charniaux-Cotton (1974) obtained total destruction of oogonia in Orchestia gammarellus. Busulfan had the same effect on the male gonad (personal communication).

\section{Experimental conditions.}

Continuing to work on control of sexual differentiation in the Colorado beetle, we studied the gonad function, and particularly the relationships between germ and mesodermic cells. We implanted busulfan into the larvae and imagos of the Colorado beetle to produce gonads deprived of germ cells and to analyze the role of mesodermic tissue A busulfan crystal * was implanted in the abdomen near the gonads. Larvae of

* The Techni-Pharma Laboratories kindly furnished us the busulfan recrystallized when cold from a chloroformic solution. 
instars 1,2 and 3 , as well as adults, received a single implantation. We used $60 \mu \mathrm{g}$ for $100 \mathrm{mg}$ of animal. A higher amount such as $80 \mu \mathrm{g}$ is lethal, while $30 \mu \mathrm{g}$ has no effect. Busulfan has been used on few species and we cannot evaluate the optimal dose which sterilizes insects without increasing mortality. When given to the imagos of coleoptera Anthonomus grandis in a synthetic meal containing 8 p. 100 busulfan, this product causes high mortality. After a 3-day treatment, mortality reaches 30-80 p. 10014 days later. However, the doses cannot be compared when busulfan is given orally.

Larvae were killed 5, 7, 10, 12 and 14 days after implantation and studied histologically.

TABLE 1

\begin{tabular}{|c|c|c|c|c|c|}
\hline Age of animals treated & L1 & L2 & L3 & L4 & Imago \\
\hline Number of animals implanted.......... & 367 & 20 & 18 & 00 & 22 \\
\hline Number of stage 4 larvae obtained..... & 54 & 12 & 4 & 00 & - \\
\hline Number of adults obtained.:......... & 00 & 00 & 202 ㅇ & 00 & 00 \\
\hline Post-treatment mortality (p. 100)....... & 85 & 60 & 78 & - & 100 \\
\hline
\end{tabular}

\section{Effect of busulfan on molting.}

Larval mortality is high 5-6 days after implantation; adult mortality reaches 100 p. 100 (table 1).
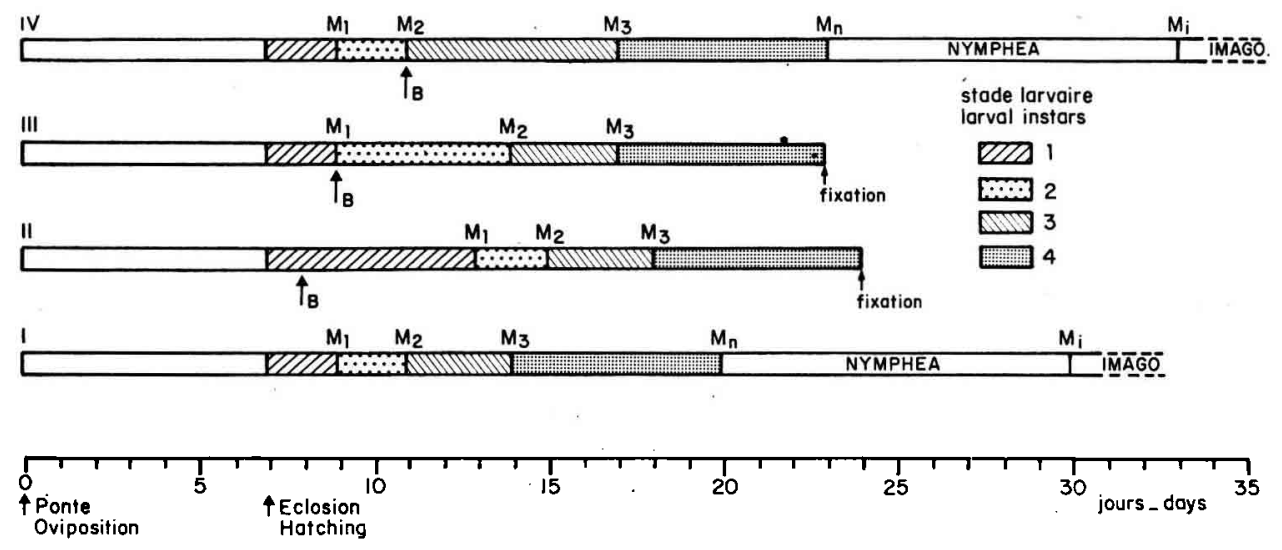

FIG. 1. - Effect of busulfan on molting.

$B$ : busulfan implanted

$M_{1}, M_{2}, \ldots$ molts. 
When busulfan is implanted in 1-day old instar 1 larvae, this stage is prolonged 4 to 5 days (fig. 1). The first molt after implantation is inhibited in many larvae, thus leading them to die. Larval molts 2 and 3 occur normally in the surviving larvae; however, pupal molting is entirely inhibited. Implantation in instar 2 and 3 larvae retards the first molt after this operation by 2 to 3 days (fig. 1) ; mortality is very high after the molt. When busulfan is introduced into instar 2 larvae, pupal molting is suppressed; however, larvae implanted at instar 3 molt normally (fig. 1). These animals reach imaginal instar. Subjects obtained after implantation were smaller than the controls ; this may be because the pupal molt was suppressed. Charpin (1976) studying another Coleoptera, suggests that there is no pupation if the prepupa does not develop to a minimal size. We were obliged to fix the larvae at the end of instar 4 because larval and pupal molts were suppressed by busulfan.

\section{Busulfan action on gonads.}

Following is a brief summary of the chronological development of male and female gonads in control animals.

\section{Histological study of control gonads.}

Colorado beetle larvae hatch after 7 days of embryonic development at $22^{\circ} \mathrm{C}$. An undifferentiated sexual stage after 4 days of embryonic life has already been reported (Richard-Mercier, 1972). This instar is brief and the next day the gonads sexually differentiate definitively. At hatching, each testis has two lobes containing primary spermatogonia and mesodermic cells. Two types of mesodermic cells may be distinguished at that time, those enveloping the gonia and those grouped at the ends of each testicular lobe in a tissue called the apical tissue. During larval instar 1, testis organization remains stable. After the first molt, primary spermatogonial mitoses begin. They are concomittant with cyst formation and there is some spermatogonial degeneration during this time. Meiotic prophases begin at instar 3 and spermatogonial mitoses continue. Larval testicular follicles at instar 4 are composed of 50 p. 100 spermatocytes $l$ at different stages of meiotic prophase and 50 p. 100 secondary spermatogonia (PI. I, fig. 4). Spermatogenesis continues during pupation.

At day 5 of embryonic development, the form of the ovary is that of a long, narrow band containing mesodermic cells scattered throughout with primary oogonia. The terminal filaments of future ovarioles are already individualized; they protrude on the latero-external edge of the gonad. Larval ovaries in instar 1 retain this structure. In larval instar 2, the mesodermic tissue proliferates and, with the oogonia, composes the germarium. Oogonial mitotic activity, sporadic in instar 2, increases in instar 3 larvae and intensifies in the following instar. At instar 4 , the germarium is prolonged by a solid cord in which a duct appears, followed by the mesodermic oviduct. This cord later constitutes the vitellarium and a duct, the pedicel. Very often at the end of instar 4, an oocyte may be found entering the part of the vitellarium called the transitory zone. 
Histological study of experimental animal gonads.

Five days after busulfan is introduced in instar l larvae, the first larval molt occurs ; these larval gonads, are then comparable to those of instar 2. In male and female gonads, gonial division is blocked at metaphase. The chromosomes, usually hard to see, are minute and intensely stained.

Seven days after implantation, there are many gonial pyknoses (table 2). They are the result of the degeneration of gonia in which mitosis has been inhibited. This process is more marked in male (PI. I, fig. 1) than in female (PI. I, fig. 2) gonads. Mitotic activity resumes; it is similar to that in the controls and is especially intense in female gonads. The number of oogonial mitoses increases at larval instar 3 in female gonads.

Ten, 12, 14 days later, larvae implanted at the beginning of instar 1 present gonads histologically similar to those of the controls* but 3 times smaller. This difference in size is due to a smaller number of testicular cysts, and in the female gonad, to a smaller germarium.

In animals implanted at larval instars 2 and 3, gonial mitoses are suppressed then resumed 7 days after busulfan implantation. The most significant effects were obtained on male larvae implanted at instars 2 and 3 and killed 14 and 12 days later, respectively. Their testes were always 3 times smaller than the controls*. There were fewer cysts and many were empty, only their walls being visible (PI. I, fig. 5). These testes contain mainly spermatocyts I in meiosis prophase while gonial mitoses and secondary gonial are rare.

Busulfan effect on larval female gonads is more discrete. The germarium is smaller than in the controls and traces of oogonial pyknosis have partially disappeared (PI. I,

* Larval instar 4 continues more than 6 days due to suppression of pupal molting. Gonial evolution of these larvae is also arrested. The gonads resemble those of instar 4 larvae, while they should be similar to pupal gonads.

\section{PLATE I}

FIG. 1. - Instar 2 larva treated at instar 1 : Iongitudinal $\times$-section of a testicular follicle.

FIG. 2. - Instar 2 larva treated at instar 1 : frontal $\times$-section of an ovary.

FIG. 3. - Instar 4 larva treated at instar 2 : longifudinal $\times$-section of two ovarioles.

FIG. 4. - Instar 4 control larva : longitudinal $\times$-section of a testicular follicle.

FIG. 5. - Instar 4 larva treated at instar 2 : longifudinal $\times$-section of a testicular follicle.

c. m. : interstitial mesodermic cell ; c. spc. I. : spermatocyte l cyst ; c. spg. p. : primary spermatonia cyst ; c. spg. s : secondary spermatogonia cyst ; c. e. : emply cyst ; d. g.' : 'gonial degeneration ; f. †. : terminal filament ; g. : germarium ; m. g. : gonial mitosis ; m. spg. s. : secondary spermatogonia mitosis ; og. p. : primary oogonia ; ov. : oocyte ; p. : pedicel ; $t$ a. : adipose tissue ; t. M. : Malpigian tubule. 

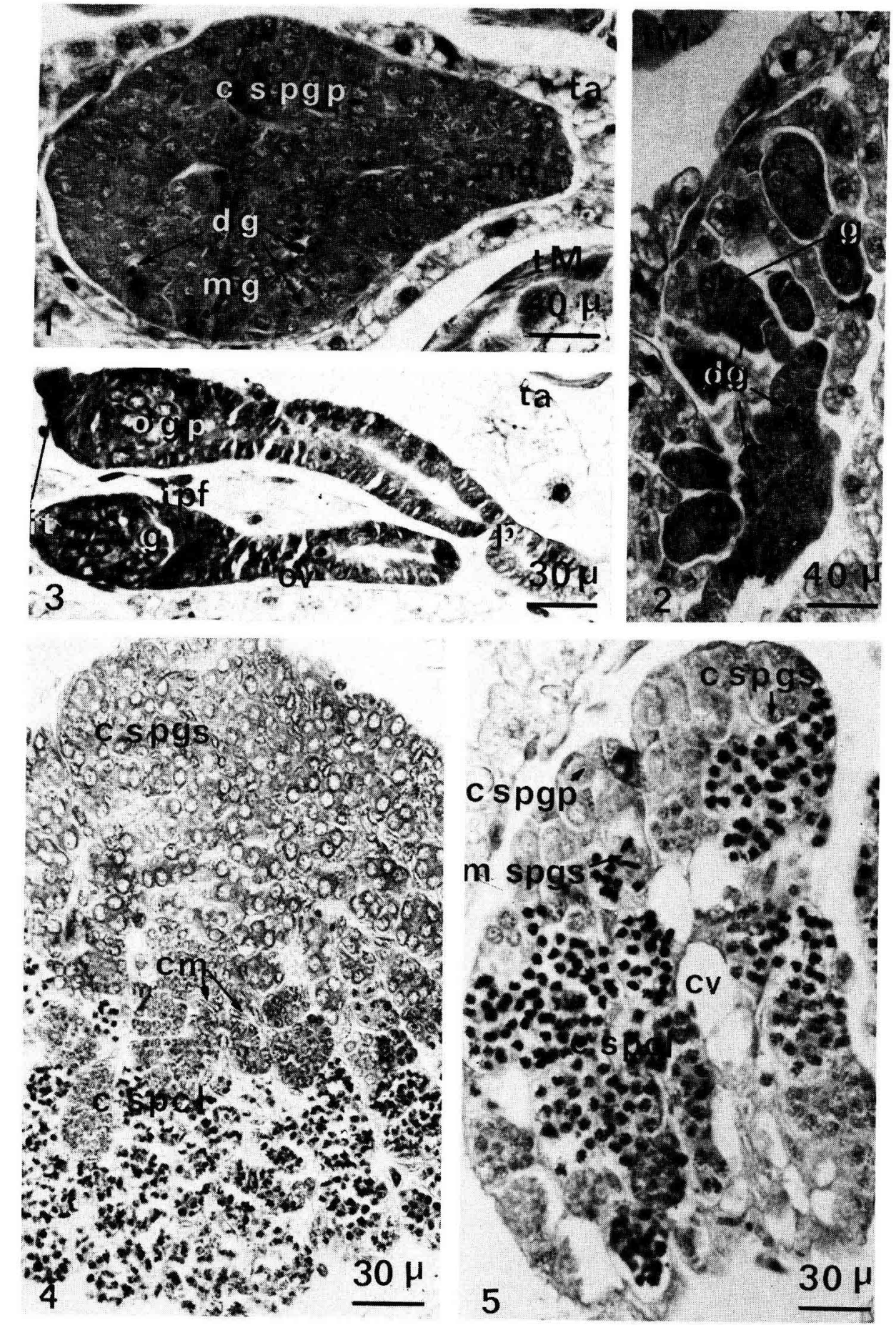

cspgín
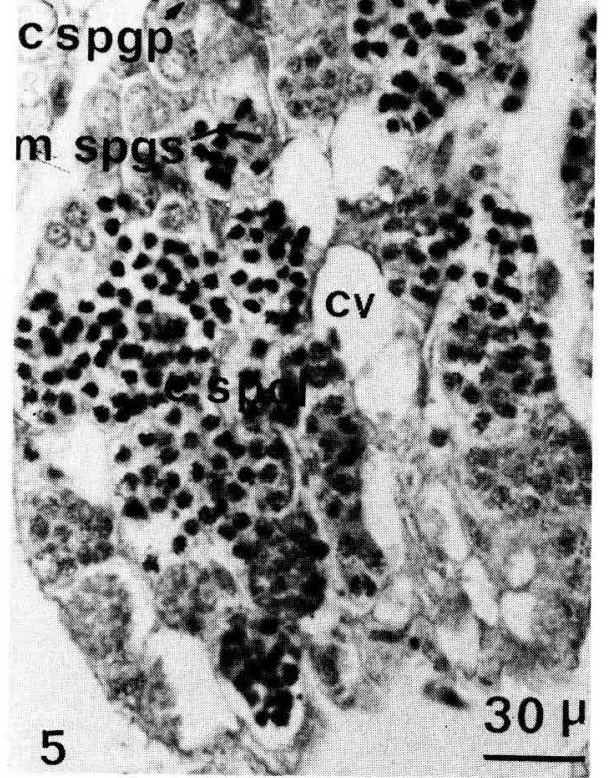
N. RICHARD-MERCIER

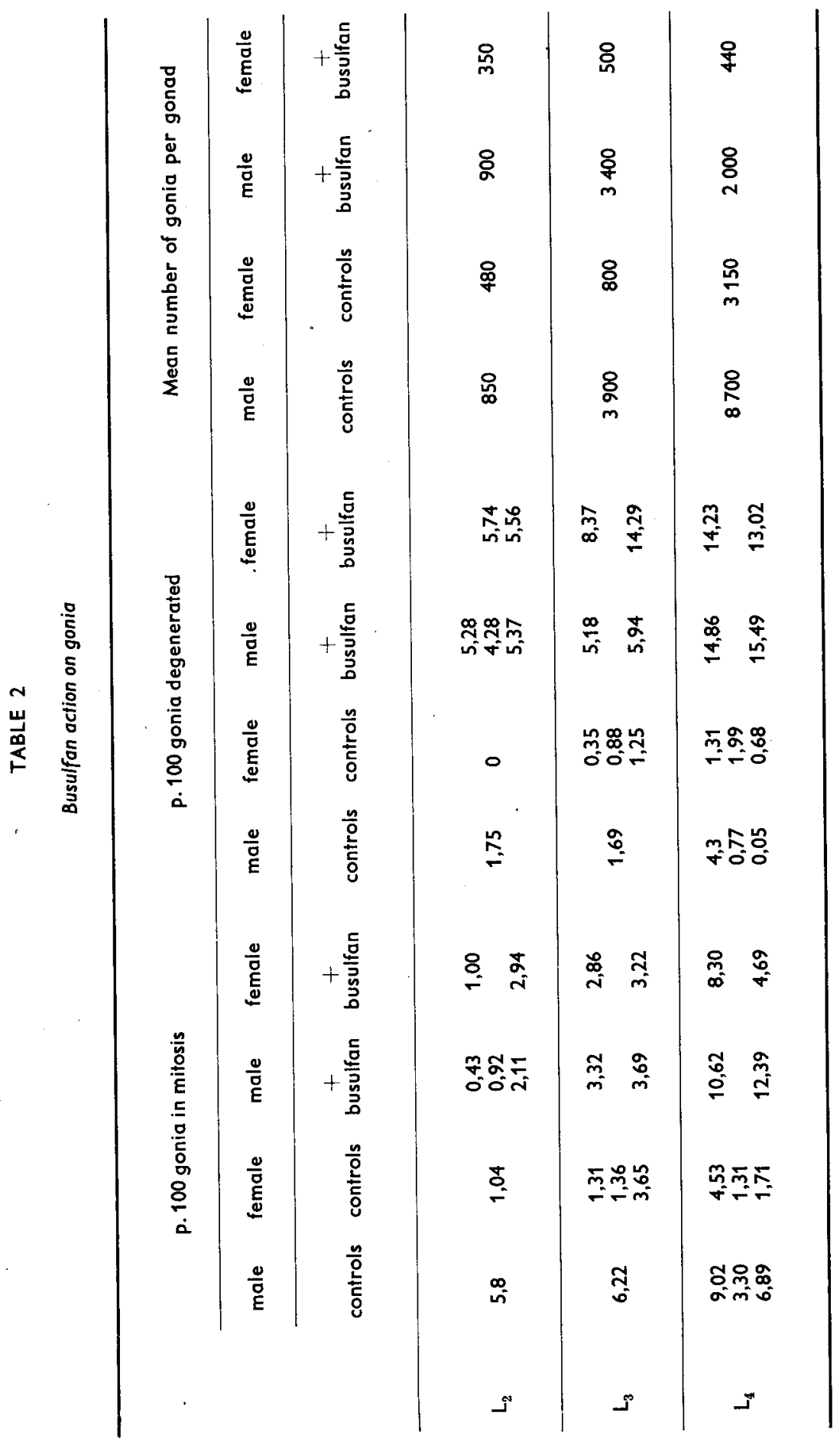


fig. 3). In larvae implanted at instar 2 and examined at instar 4 , the oocyte entering the prefollicular cell cord is degenerate. Among the larvae implanted with busulfan at instar 3, four reached the imaginal instar. These imagos reproduced normally. Egg laying, at first abundant, became rarer after 3 weeks. Unfortunately, these fragile animals died so they could not be studied.

Busulfan acts on the gonia during mitosis. In the testes and ovaries of experimental larvae, the percentage of gonia in mitosis (table 2) is significantly higher than in the controls. This is because we did not distinguish between normal and abortive mitoses. This study confirms that busulfan acts during mitosis. Gonial necroses occur later and increase with the number of gonia in mitosis (table 2). The oogonia of the 3 rd instar are more sensitive than spermatogonia to busulfan ; its implantation, however, causes a sharp decrease in the number of gonia of both sexes.

Gonad mesodermic tissue was not affected by busulfan in these experiments.

\section{Discussion.}

Colorado beetle larvae, after implantation of a busulfan crystal, are smaller than control larvae. This may be due to degeneration during the numerous hypodermic cell mitoses in larvae. Busulfan also affects molting. The first larval molt after implantation is suppressed. The pupal molt may be inhibited or occur normally, depending on the age of the larvae. These observations complete those on Diptera larvae treated with other antimitotics (Poitrineau ef al., 1973 ; Le Bras, 1973).

In the Colorado beetle gonads busulfan partially destroys one type of cells, the secondary gonia. Various radiomimetic agents (antimitotics, $X$-rays, neutrons) do, in effect, destroy the germ cells of many insects at the secondary gonial instar (Landa and Matolin, 1969). The action of several antimitotics on insect gonads is presented in tables 3, 3 bis. Our experiments demonstrate that busulfan causes chromosomic changes during mitoses and finally cell necrosis. Other antimitotics (table 3) such as metepa and tetramine also induce fragmentation and chromosomic bridges in two Diptera. These changes have also been reported in mammals (Pinto-Machado, 1968a, b).

At the time of implantation in our experiments, spermatogonial mitoses are more numerous than oogonial ones, and degeneration is more extensive in the testis than in the ovaries. This confirms the observations of Kissam ef al. (1967). Busulfan partially destroys germinal tissue but leaves intact the mesodermic tissue of the Colorado beetle larval gonads. However, other antimitotic agents affect the follicular tissue of adult insect gonads. They cause either destruction of that tissue or its abnormal proliferation. The necrosis of follicular tissue is explained by its numerous mitoses. In rat, follicular (Rateau, 1974) and Sertoli (Hemsworth and Jackson, 1962) cells are unaffected by busulfan, although they actively divide. All proliferating cell types are affected by metepa, tretamine and tepa, although they do not react in this way to busulfan. As in rat, the small size of Colorado beetle gonads implanted with busulfan is solely a result of gonial degeneration. Other antimitotics cause necroses of germ cells and mesodermic cells which together reduce gonad zize (table 3). Antimitotics induce partial destruction of gonia, thus preventing analysis of their relationship to mesodermic cells. 


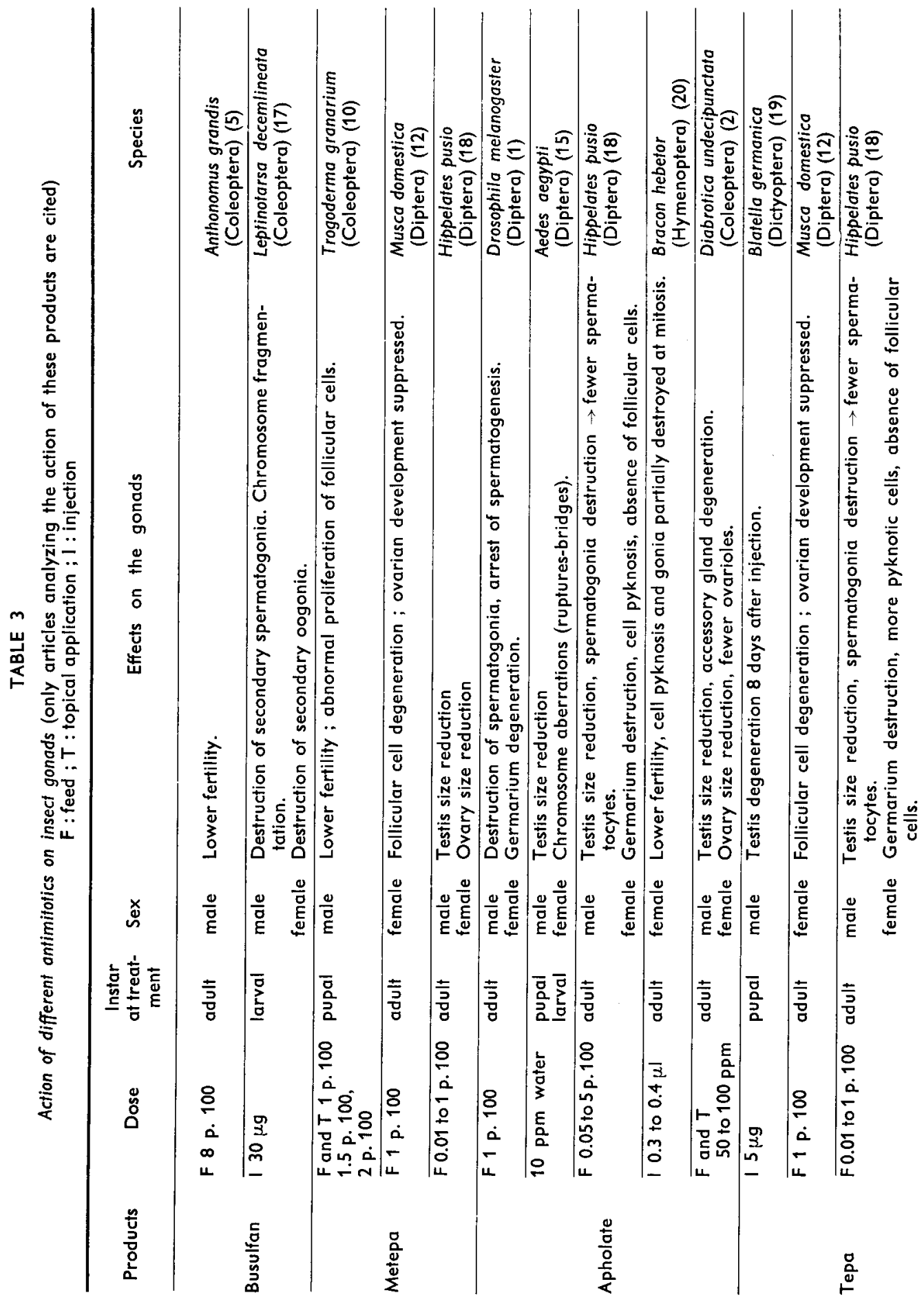




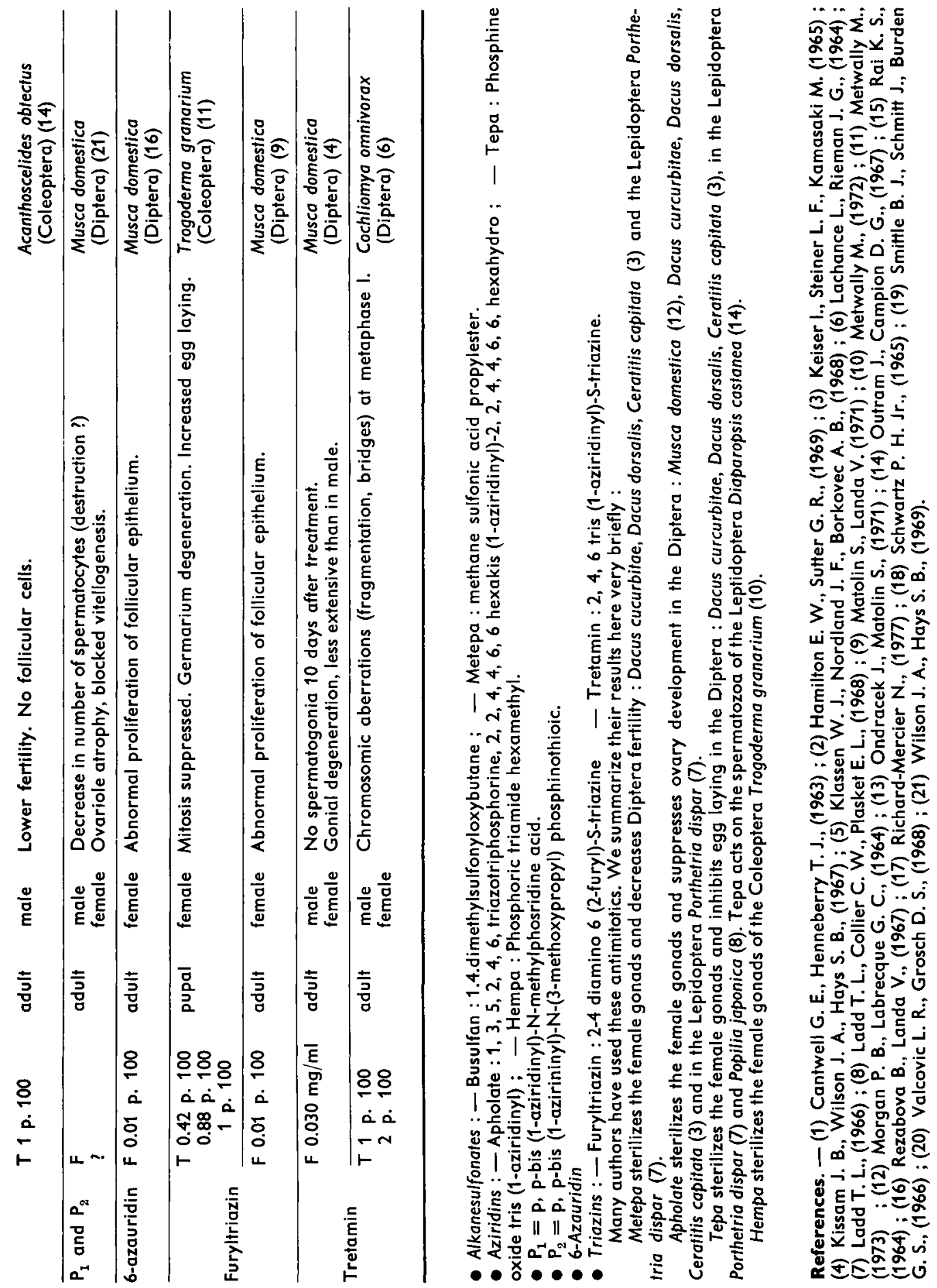


TABLE 3 bis

\begin{tabular}{|c|c|c|c|c|c|}
\hline Products & Dose & $\begin{array}{l}\text { Instar } \\
\text { at } \\
\text { treatment }\end{array}$ & Sex & Effects on the gonads & Species \\
\hline Metepa & F 2 p. 100 & adult & female & $\begin{array}{l}\text { Follicular cells and oocyte } \\
\text { degeneration. Interfollicular } \\
\text { tissue necrosis. }\end{array}$ & $\begin{array}{l}\text { Periplanela } \\
\text { americana } \\
\text { (Orthoptera) }\left(^{2}\right)\end{array}$ \\
\hline Hempa & $\begin{array}{l}10.2 ; 0.5 \mathrm{mg} \\
10.001 ; 0.005 ; \\
0.1 \mathrm{mg}\end{array}$ & adult & $\begin{array}{l}\text { male } \\
\text { female }\end{array}$ & $\begin{array}{l}\text { Destruction of spermatogonia, } \\
\text { spermatocytes and early } \\
\text { spermatides. } \\
\text { Follicular cells degeneration. } \\
\text { Vitellogenesis inhibition. }\end{array}$ & $\begin{array}{l}\text { Locusta } \\
\text { migraforia } \\
\text { (Orthoptera) (1) }\end{array}$ \\
\hline $\begin{array}{c}\text { Apholate } \\
\vdots\end{array}$ & F 2 p. 100 & adult & female & $\begin{array}{l}\text { Follicular cells and oocyte } \\
\text { degeneration. Necrosis of } \\
\text { interfollicular tissue. }\end{array}$ & $\begin{array}{l}\text { Periplaneta } \\
\text { americana } \\
\text { (Orthoptera) }\left(^{2}\right)\end{array}$ \\
\hline
\end{tabular}

(1) Nath V., Mittal P. K., Sheiker C. (1976) ; $\left({ }^{2}\right)$ Tandon G. N., Bhargava S. (1977).

Our results confirm the impossibility of totally sterilizing insect gonads. The effect of antimitotics on cells of Diptera may be applied to Coleoptera.

Reçu en décembre 1976.

Accepté en février 1977.

Résumé. Un cristal de busulfan, implanté dans des larves de $1^{\mathrm{er}}, 2^{\mathrm{e}}$ et $3^{\mathrm{e}}$ stades, provoque un bloquage temporaire de la mue. Dans les gonades, cet antimitotique ne détruit qu'une catégorie de cellules germinales : les gonies secondaires. C'est au moment de leur mitose que se révèlent les altérations chromosomiques entraînant la dégénérescence cellulaire. Cependant, toutes les gonies ne sont pas atteintes par une dose unique de busulfan.

\section{References}

BOLLAG W., 1953. Der Einfluss von Myleran auf die Keimdrussen von Ratten. Experientia, 9, 268. CANTWELL G. E., HENNEBERRY T. J., 1963. The effects of gammaradiation and apholate on the reproductive tissues of Drosophila melanogaster. J. Insect Pathol., 5, 251-264.

CHARNIAUX-COTTON H., 1974. Données nouvelles concernant la vitellogenèse des Crustacés Malacostracés obtenues chez l'Amphipode Orchestia gammarellus (Pallas) : folliculogenèse à partir d'un tissu permanent ; action du busulfan ; action inhibitrice de l'hormone juvénile. C. R. Acad. Sci. Paris, série D, 276, 563-566.

CHARPIN P., 1976. Evolution pondérale et physiologique de la larve de Choleva angustata Fab. au cours du dernier stade. C. R. Acad. Sci. Paris, série D, 283, 931-934.

GILLET J., LAPORTE P., 1973. Effets du busulfan et de FSH sur les fubes séminifères du Rat : changements morphologiques et cellulaires. Arch. Anat. micr. Morphal. exper. Fr., 62, 385-398.

HAMILTON E. W., SUTTER G. R., 1969. Chemosterilizing southern corn root worm beetles with apholate. J. econ. Entomol., 62, 1285-1288.

HEMSWORTH B. N., JACKSON H., 1962. Effect of busulfan on the fœtal gonad. Nature, 195, 816817.

KEISER I., STEINER L. F., KAMASAKI H., 1965. Effect of chemosterilisants against the oriental fruit fly, melon fly, and mediterranean fruit fly. J. econ. Entomol., 58, 682-685. 
KISSAM J. B.; WILSON J. A., HAYS S. B., 1967. Selective effects of certain anfi-fertility compounds on the house fly as shown by reciprocal crosses and histological sectionning. J. econ. Entomol., 60, 1130-1135.

KLASSEN W., NORDLAND J. F., BORKOVEC B., 1968. Potential chemosterilization for the boll wevil. J. econ. Entomol., 61, 401-407.

LACHANCE L. E., RIEMANN J. G., 1964. Cytogenetic investigations on radiation and chemically induced dominant lethal mutations in oocytes and sperm of the screw-worm fly. Mutation Research, 1, 318-333.

LADD T. L. Jr, 1966. Egg viability and longevity of japonese beetles treated with tepa apholate and metapa. J. econ. Entomol., 59, 422-425.

LADD T. L., COLLIER C. W., PLASKET E. L. 1968. Mass sterilization of japonese beetles with tepa and the determination of residues. J. econ. Entomol., 61, 942-944.

LANDA V., MATOLIN S., 1969. Effects of chemosterilants on reproductive organs and embryogenesis in Insects. Coll. inter. CNRS, Tours, 411-420.

LE BRAS S., 1973. Toxicité comparée de la thiourée et de l'hempa sur Musca domestica aux divers stades de développement. Action stérilisante de l'hempa sur l'insecte adulte. Ann. Zool. Ecol. Anim. Fr., 5, 351-360.

MATOLIN S., LANDA, V., 1971. The effect of furyltriazine on oogenesis and embryogenesis in Musca domestica L., Acta ent. bohemoslov., 68, 1-5.

METWALLY M., 1972. Effects of metepa and tepa on the ovarian development of the Khapra beetle, Trogoderma granarium Everts. Acta ent. bohemoslov., 69, 229-242.

METWALLY M. M., 1973. Effects of furyltriazine on the ovarian development of Trogodermo granarium (Coleoptera, Dermestidae) Z. ang. Ent., 74, 274-281.

MORGAN P. B., LABRECQUE G. C., 1964. Effects of tepa and metepa on ovarian development of house fly. J. econ. Entomol., 57, 896-899.

NATH V., MITTAL P. K., SHEIKER C., 1976. Effects of hempa on the gonads of Locusta migratora L. (Orthoptera, Acrididae). Bull. ent. Res., 66, 313-315.

ONDRACEK J., MATOLIN S., 1971. Effects of the chemosterilisant tepa on the female reproductive system and embryogenesis of Acanthoscelides obtectus Say. (bean beetle). Acta ent. bohemoslov. 63, 209-215.

OUTRAM J., CAMPION D. G. 1967. Morphology of the male reproductive system and spermatophore of the reb bollworm, Diparopsis castanea (Hmps) and the possible effect of the chemosterilant tepa on the gross structure. Ann. appl. Biol., G. B., 60, 439-444.

PINTO-MACHADO J., 1968a. Influence du busulfan sur le développement prénatal de la souris. Arch. porfug. Sci. biol., 16, 77-108.

PINTO-MACHADO J., 1968b. Influence du busulfan sur le développement prénatal de la souris. Arch. portug. Sci. biol., 16, 5-31.

POITRINEAU H., BEYTOUT D., BASTIDE P., 1973. Action de quelques antomitofiques sur le développement des larves d'Aedes aegypti. C. R. Soc. Biol. Fr., 167, 282-285.

RAI K. S., 1964. Cytogenefic effects of chemosterilants in mosquitoes. I. Apholate-induced aberrations in the somatic chromosomes of Aedes aegypti. Cytologia jap., 29, 346-353.

RATEAU J. G., 1974. Etude de la différenciation de l'ovaire du Rat après le traitement par le bulsulfan. C. R. Soc. Biol., Fr., 168, 1163-1167.

REZABOVA B., LANDA V., 1967. Effect of 6-azauridine on the development of the ovaries in the house fly Musca domestica L. (Diptera). Acta ent. bohemoslov., 64, 344-351.

RICHARD-MERCIER N., 1972. Embryogenèse et différenciation sexuelle de la gonade du Doryphore Leptinotarsa decemlineata Say (Coléoptère chrysomélide). Ann. Embryol. Morph., 5, 191-201.

SCHWARTZ PH. Jr. 1965. Effects of apholate metepa and tepa an reproductive tissues of Hippelates pusio. J. Invert. Pathol., 7,, 148-151.

SMITTLE B. J., SCHMITT J., BURDEN G.S.1966. Effect of tepa on the reproductive organs and embryogeny of the german cokroach. J. econ. Enfomol., 59, 1419-1423. 
TANDON G. N., BHARGAVA S., 1977. Effect of certain alkylating chemosterilants on the ovarian structure american coachroach. (Orthoptera : Blattidae). Current Science, 46, 133-135.

VALCOVIC L. R., GROSCH D. S., 1968. Apholate induced sterility in Bracon hebefor. J. econ. Entomol., 61, 1514-1517.

WILSON J. A., HAYS S. B., 1969. Histological changes in the gonads and reproductive behavior of house flies following treatment with chemosterilants, p., p-bis (1-aziridinyl)-N-methylphosphinic amide and p, p-bis (1-aziridinyl)-N-(3-methoxypropyl)-phosphinothioic amide. J. econ. Entomol., 62, 690-692. 